اثر دَر آسيبى غلظتهاى متفاوت عصاره آبى نه گونه علف هرز بر شاخصهاى جوانهزنى بذر و

رشد كياهجه انيسون (Pimpinella anisum)

\author{
زهرا عجريبزاده '، حميدرضا بلوجى ‘،"، عليرضا يدوى ‘، امين صالحى؟ \\ دانشجوى كارشناسى ارشد علوم و فناورى بذر تروه زراعت و اصلاح نباتات، دانشكده كشاورزى، دانشگاه ياسوج

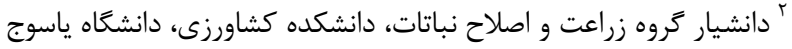

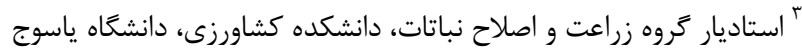

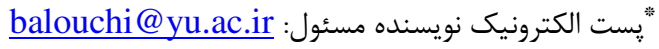

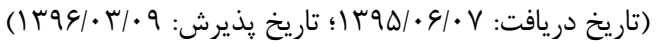

بلهمنظور بررسى تأثير دكر آسيبى عصاره آبى نه كونه علف هرز بر شاخصهاى جوانهزنى بذر و رشد كياهجه

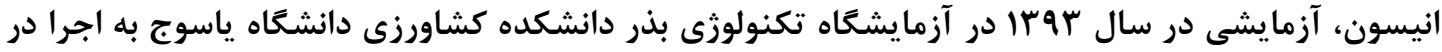

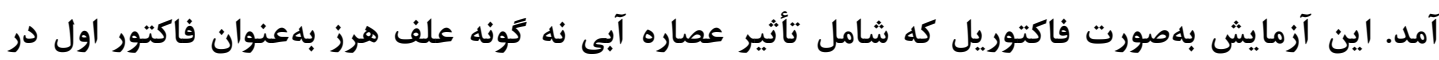

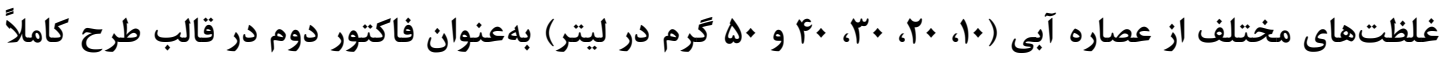

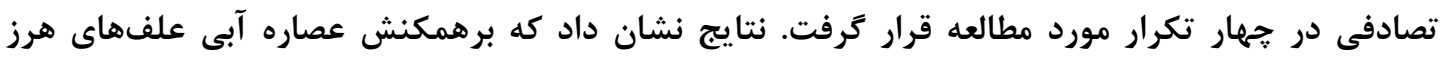

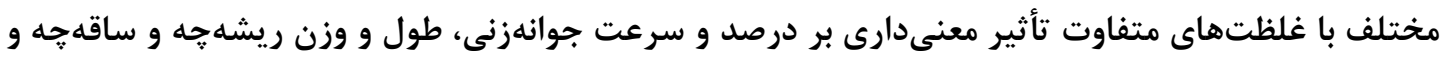

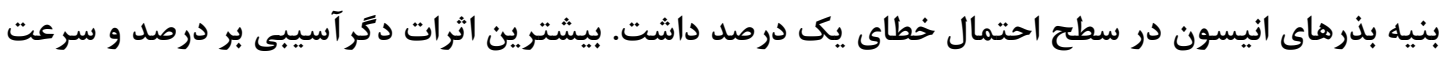

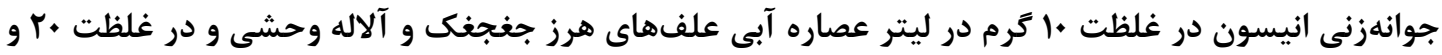

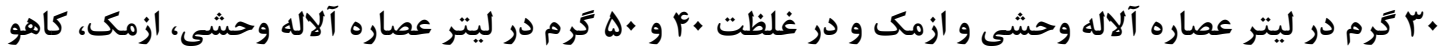
وحشى و جغجغك مشاهده شد و جوانهزنى بذر انيسون را به صفر رساند. وازههاى كليدى: آللوياتى، بنيه بذر، درصد جوانهزنى، رشد گياهجه، علفكش زيستى -انتخابى جنبههاى نوآورى:

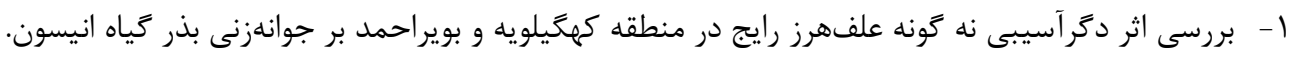

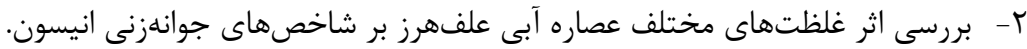

همكاران، سوب(ا). در واقع مواد شيميايى با خاصيت مقدمه

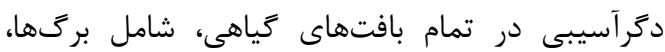
يديده آللوياتى، تداخل شيميايى يك گونه كياهى با

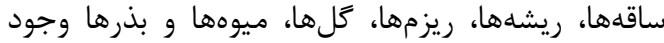

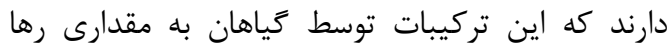

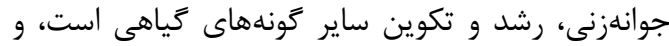

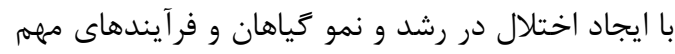

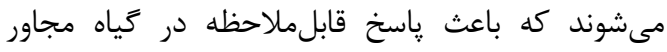

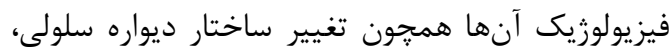

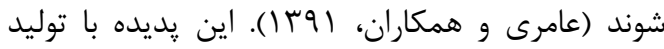

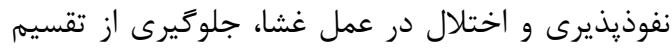
متابوليتهاى ثانويه بهوسيله كياهان، ميكروار كانيسمها،

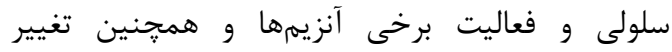
ويروسها و قارجها، مىتواند رشد و توسعه سيستمهاى تباى

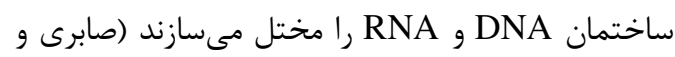


آبى آفتابخردان را ناشى از تخريب غشاء سلولى در كياهجههاى خردل وحشى عنوان نمودند.

كنترل علفهاى هرز در مرحله جوانهزنى و استقرار بذر مىتواند نقش بسزايى در كاهش خسارت علفهاى

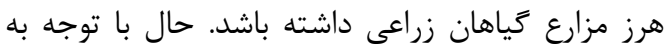

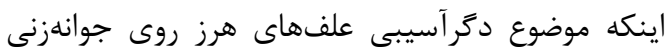
كياه دارويى انيسون كمتر موردبررسى قرار كرفته است و و

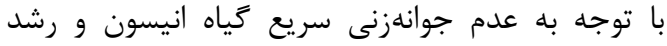
سريع علفهاى هرز در مزارع اين كياه، لذا هدف از اين آزمايش مطالعه اثرات دكرآسيبى غلظتهائ آراى مختلف عصاره آبى جندَّونه علف هرز، كه در استان كهذيلويه و بويراحمد رايج مىباشند، روى شاخصهاى جوانهزنى انيسون مىباشد.

مواد و روشها

يزوهش حاضر بهمنظور تعيين دكر آسيبى غلظتهاى

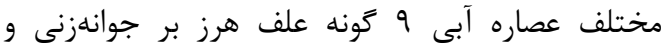
مراحل اوليهى رشد كياه دارويى انيسون، در سال بهوبا در آزمايشحاه تكنولوزى بذر دانشكده كشاورزى دانشخاه

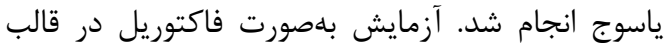

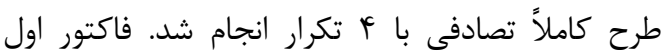

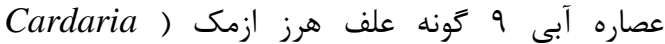
(draba )، بارهنَ (Plantago lanceolata)، آلاله

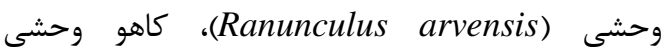
(Gactuca virosa)

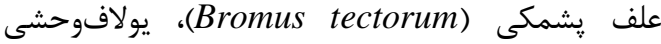
(Vaccaria pyramidata) (Avena fatua) و ماشك كل خوشهاى (Vica villosa)، فاكتور دوم

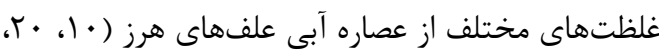

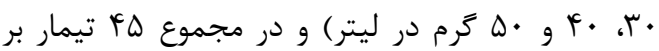
جوانهزنى و رشد بذرهاى انيسون انجام شد. قبل از اعمال تيمارها، همه شاخصهاى جوانهزنى بذرهاى انيسون در شرايط بدون اعمال عصاره آبى علف هرز نيز

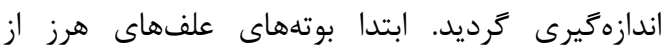
جندين منطقه در ياسوج جمعآورى و شستشو شدند.

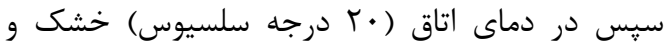

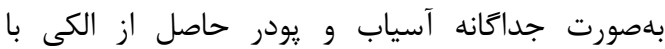
سوراخهايى به قطر 1 ميلىمتر عبور داده شد. جهت
بيولوزيكى و نيز كشاورزى را تحت تأثير قرار دهد

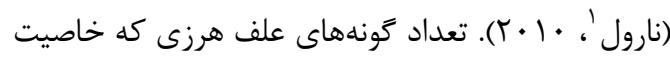

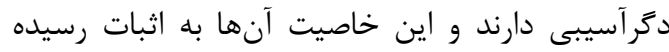

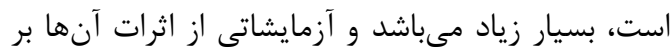

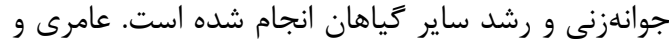

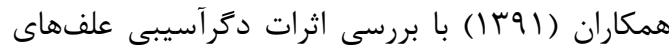
هرز تاجخروس (Amaranthus retroflexus)، سلمهتره Cynodon (Chenopodium album) (Cyperus difformis) ، dactylon

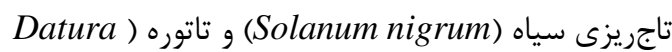

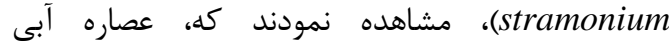
علفهاى هرز يادشده در غلظتهاى مختلف روى خصوصيات جوانهزنى بذر گياه دارويى هميشهابهار اثرات

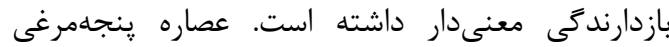

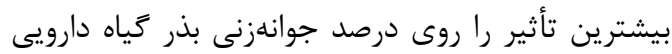

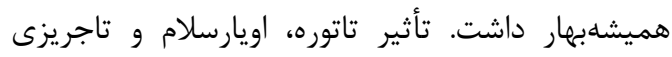
روى درصد جوانهزنى كمتر از ينجه مرغى بود. كمترين

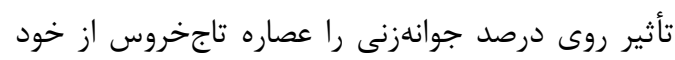

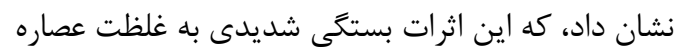

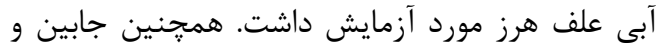

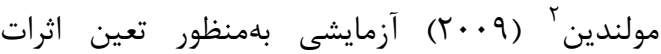

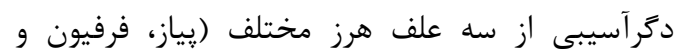
شاهتره) بر رشد ذرت انجام دادند. مشاهده شد كه يودر حاصل از علفهاى هرز بر رشد ذرت اثرات مهارى داشته

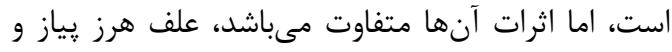
شاهتره درصد و شاخص جوانهزنى را بيشتر كاهش داده انها

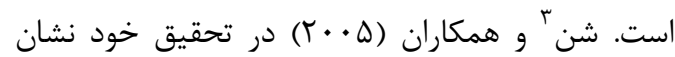
دادند كه علفهاى هرز مختلف از جمله سلمه، تاتوره و و

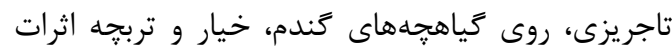
دكرآسيبى دارند. نتايج آنان نشان داد كه عصاره اندام

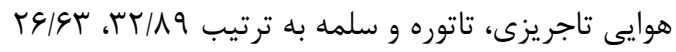

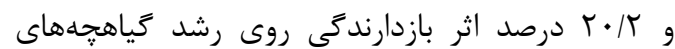
محصولات فوق داشتند. در آزمايشى فرهودى و همكاران

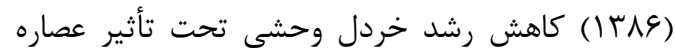

\footnotetext{
${ }^{1}$ Narwal

${ }^{2}$ Jabeen and Molnuddin

${ }^{3}$ Shen
} 
اين برنامه D50 (يعنى مدتزمانى كه طول مى كشد تا

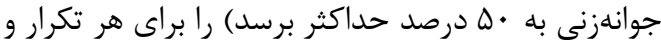
هر تيمار بذرى از طريق درونيابى منحنى افزايش

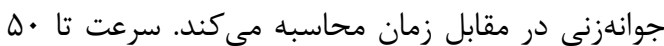
درصد جوانهزنى (بر روز) از طريق رابطه 1 محاسبه

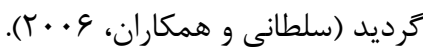
رابطه ):

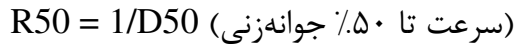
درصد بذرهاى جوانهزده (GP) از رابطه r محاسبه كرديد.

رابطه r

تعداد بذرهاى جوانهزده و N كل تعداد بذرهاى

كشتشده.

سرعت جوانهزنى (GR) از رابطه ب محاسبه كرديد

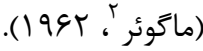

$\mathrm{GR}=\Sigma^{\mathrm{n}}{ }_{\mathrm{i}=1}\left(\mathrm{~N}_{\mathrm{i}} / \mathrm{D}_{\mathrm{i}}\right)$ رابطه rا:

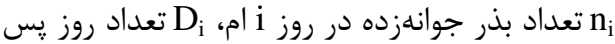

$$
\text { از شروع آزمايش }
$$

همجنين شاخص طولى و وزنى بنيه گَياهجه طبق رابطه f و و ه محاسبه شدند (اكبراقدمى و همكاران،

. (1r9t

LSVI= $($ GP/100 $\times$ Seedling L) : : WSVI= (GP/100)×(Seedling W) :

$$
\begin{aligned}
& \text { LSVI } \\
& \text { = درصد جوانهزنى = GP } \\
& \text { Seedling L } \\
& \text { شاخص بنيه وزنى كياهجه } \\
& \text { = Seedling W }
\end{aligned}
$$

محاسبات آمارى با استفاده از نرمافزارهاى SAS و Excel حداقل اختلاف معنىدار (LSD) در سطح احتمال هـ

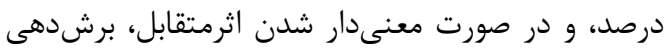

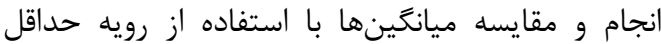

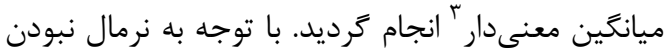
توزيع دادها، در صفات طول و وزن خشك ريشه ساقه קه، و شاخص طولى و وزنى بنيه كَياهجه، قبل از
تهيه محلول مقدار ذكرشده از يودر حاصله از هر يك از

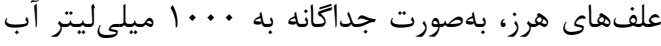

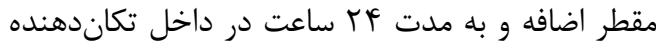
(شيكر) با سرعت • r ا دور در دقيقه قرار داده شدند (اصغرىيور، (1) (1). يس از عبور عصاره از كاغذ صافى، براى خالصسازى عصارهها، نمونههاى بهدست آمده به

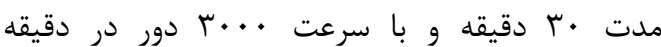

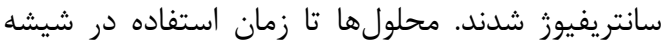
تاريك و در دماى يخجال (4 درجه سلسيوس) نكمهدارى شدند. ابتدا كليه ظروف تهيه محلول و يترىها در درائ اتوكلاو با دماى | | | درجه سانتى كراد ضدعفونى شدند، و بذرهاى انيسون بهوسيله محلول ه درصد هييوكلريت سديم به مدت ه دقيقه ضدعفونى و سيس بلهوسيله آب

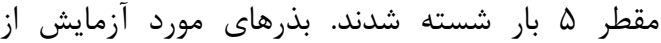

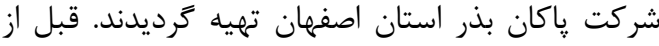
آزمايش اصلى، قوه ناميه بذرها تهيهشده انيسون اندازهخيرى و از زندهبودن بذرها اطمينان حاصل شد. سيس در كف هر يترى

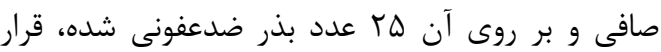

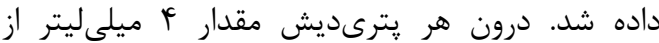
عصاره تهيهشده اضافه و درب يترىديشها توسط دئل

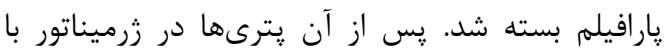

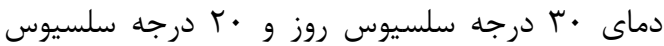
شب و دوره روشنايى/تاريكى به نسبت مساوى (T)

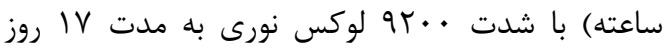

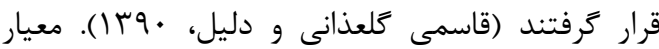
جوانهزنى خروج r ميلىمتر ريشه קه از بذر مى باشد. در

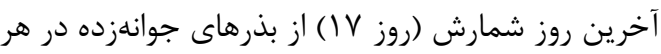

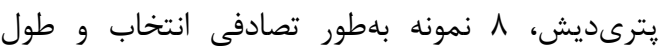

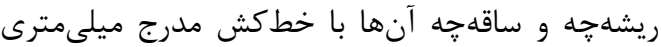

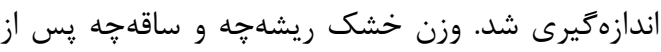

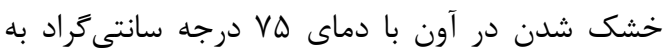

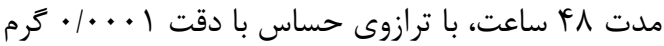
اندازهيرى شد. سرعت تا •له درصد جوانهزنى بعد از كشت با شمارش روزانه بذور سبز شده توسط برنامه Germin

\footnotetext{
${ }^{1}$ Soltani 
A). شجيع و همكاران (IYVVV نيز كزارش نمودند كه

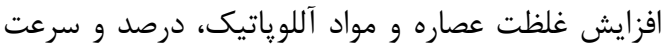
جوانهزنى بذور جو را بلهطور معنى دار كاهش مىدهد. اين نتايج را اينكونه مىتوان توجيه كرد كه يديده آللوياتى

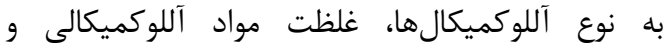

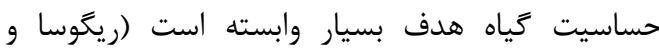

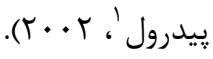

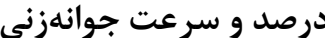

با توجه به جدول مقايسه ميانخين دادهها كمترين

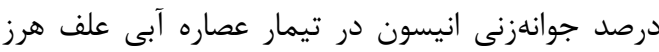
جغجغك بود، كه اختلاف معنى دارى با عصاره آبى علف آنف

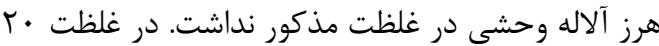

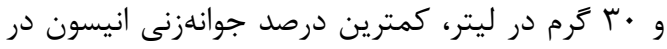
تيمار عصاره آبى علف هرز آلاله وحشى و ازمكى مشاهده دئ دروند

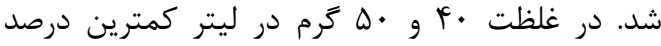

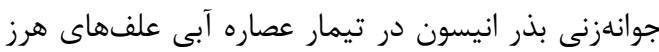

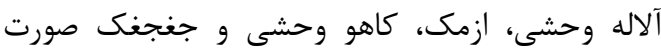
كرفت و جوانهزنى را به صفر رساند. در كل عصاره آبى آنى علف هرز علف يشمكى بيشترين درصد جوانهزنى انيسون

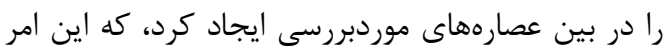
نشاندهنده اثرات كم مواد آللوياتيك موجود در عصاره آبى علف هرز علف يشمكى نسبت به ساير عصاره آبى نه علفهاى هرز بر جوانهزنى انيسون بود (جدول أل، ه، ك، V و A). در شاخص سرعت جوانهزنى جداول مقايسه

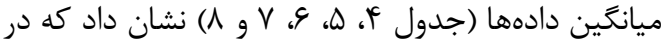

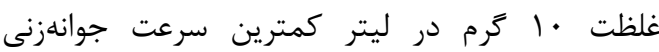
انيسون در تيمار با عصاره آبى علف هرز جغجغك به ميزان 1/ VV (بر روز) مىباشد كه با عصاره آبى علفهاى

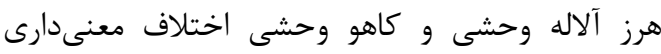

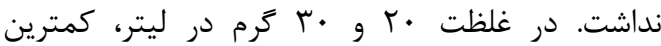
سرعت جوانهزنى انيسون در تيمار عصاره آبى علف هرز

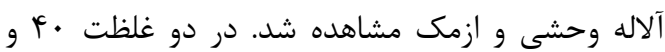

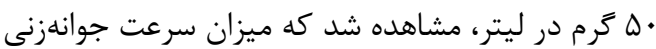
بذور انيسون در تيمار با عصاره آبى علفهاى هرز آلاله

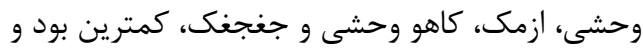

\footnotetext{
${ }^{1}$ Regosa and Pedrol
}

تجزيه واريانس تبديل دادهها بلهصوت جذر صورت كرفت.

\section{نتايج و بحث}

نتايج تجزيه واريانس دادهها نشان داد كه اثر عصاره آبى انواع علفهاى هرز و غلظتهاى مختلف عصاره و برهمكنش آنها در ارتباط با تمامى صفات موردبررسى در انيسون در سطح احتمال يك درصد معنىدار ترديد (جدول ץ). با توجه به معنى دار شدن برهمكنش صفات، برشدهى اثر عصاره آبى علفهاى هرز مختلف در غلظتهاى مختلف عصاره آن انجام شد و براى تعيين بيشترين اثر دكرآسيبى مقايسه ميانگين صفات در هر إنام غلظت بين عصاره آبى علفهاى هرز صورت كرفت

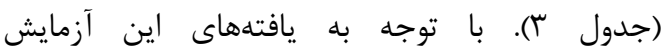
شاخصهاى جوانهزنى انيسون در شرايط شاهد (جدول () نسبت به اعمال عصاره آبى علفهاى هرز تفاوت نشان

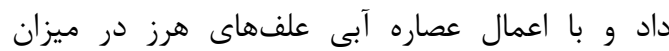

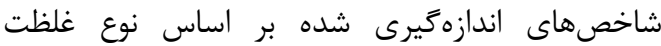
بهكاربرده شده، كاهش يافت، ولى به دليل نوع مواد

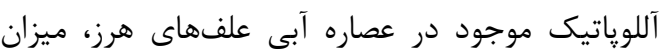
اين كاهش در عصاره آبى علفهاى هرز مختلف متغير آثران

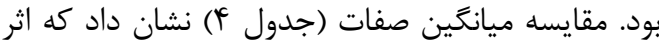

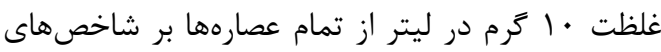

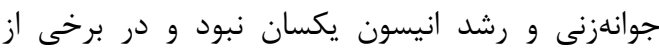

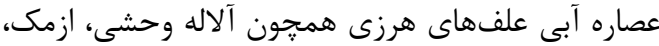
بىتيراخ، كاهو وحشى و جغجغك اين اثر بيشتر بود، كه اله اين امر را مىتوان به مواد دكرآسيبى بيشتر در اين اين بئن

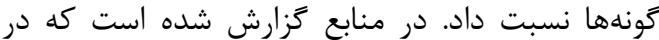

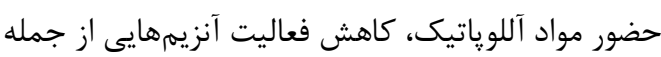
آلفآميلاز، مىتواند از دلايل كاهش سرعت جوانهزنى بذر

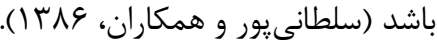

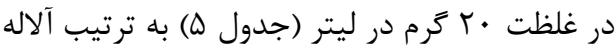

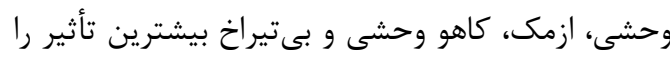

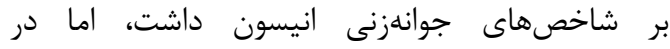

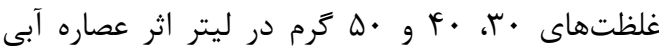
علف هرز كاهو وحشى و جغجنك تقريباً با اثرات عصاره آبى علف هرز آلاله وحشى و ازمك بر تمامى وحنى صفات

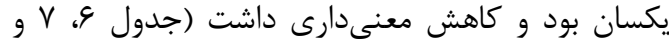




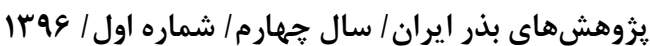

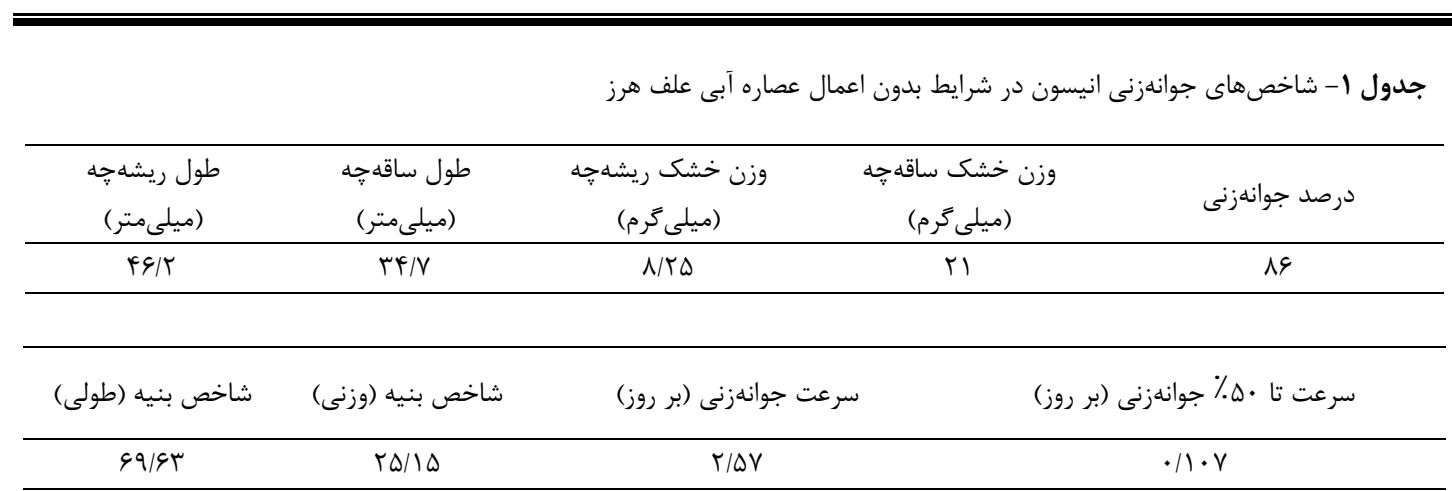

جدول r- تجزيه واريانس اثر دكرآسيبى 9 گَنه علف هرز با غلظتهاى مختلف عصاره آبى بر جوانهزنى و رشد انيسون

\begin{tabular}{|c|c|c|c|c|c|c|c|c|c|c|}
\hline 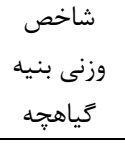 & شاخص & سرعت جـانه & خشك & خشك وزن & ساقه ֶه & ريشه ֶه & جوانهزنى سرعت & جوانهزنى درصد & آزادى درجه & منابع تغييرات \\
\hline rYM个** & rI/Vץ** & $\cdot / \cdot r \cdot * *$ & rN/rG** & $\varepsilon / V \Delta * *$ & $19 / V 1 * *$ & TN/.1** & V/rY** & $1 \cdots r r / r * *$ & $\wedge$ & علفه عصاره \\
\hline ץ.|人ץ** & $r \Delta / r \wedge * *$ & ./.rF** & $\uparrow \cdot / \cdot r * *$ & $\mid r / 4 F * *$ & rT/r人** & $r \cdot / V I * *$ & $1 \Delta / V \Delta * *$ & $1 r \Delta \cdot V / T * *$ & r & غلظت عصاره \\
\hline$r / r q * *$ & $r / \Delta \wedge * *$ & $\cdot 1$. r** & $r / \Delta \wedge * *$ & $1 / 1 V^{* *}$ & $T / T V * *$ & r/Vq** & $\cdot \mid \Delta Y^{*} *$ & VDY/G** & Tr & عصاره علفهرز \\
\hline.$/ 1 T$ & $\cdot 111$ & • &.$/ 14$ & $\cdot 1 \cdot \Delta$ & $\cdot 1 \cdot V$ & $\cdot / 10$ & $\cdot 1 \cdot r \Delta$ & $19 / 94$ & $1 r \Delta$ & خطا \\
\hline
\end{tabular}

جدول r - تجزيه واريانس برشدهى اثر دَرآسيبى عصاره آبى 9 گ كونه علف هرز در غلظتهاى مختلف بر شاخصهاى جوانهزنى و رشد انيسون

\begin{tabular}{|c|c|c|c|c|c|c|c|c|c|c|}
\hline شاخص & شاخص زياهج بنيه & 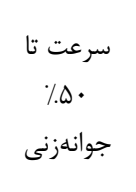 & وزاقه خشك & ريش وزن & ساقه جه & ريشه & جوانهزنى سرت & جوانهزنى درصد & آزادى درجه & غلظ عصاره \\
\hline$r / 1 \cdot * *$ & 1/94** & $\cdot / \ldots \mid 1 * *$ & $1 / r V^{*} *$ & . $\mid 94 * *$ & $\cdot / \Upsilon \Lambda * *$ & $T / 19 * *$ & 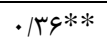 & rIV/4** & $\wedge$ & 1. \\
\hline q/६భ** & $11 / 9 V^{*} * *$ & $\cdot / \cdots \wedge$ ^** & $\mid r / T V * *$ & r/Tץ** & $4 \mid \Lambda \Lambda * *$ & $V / F V * *$ & $r / \Gamma \cdot * *$ & ґی../.** & $\wedge$ & $r \cdot$ \\
\hline$|r / r| * *$ & $11 / r 4 * *$ &.$/ .94 * *$ & $|r / \cdot| * *$ & f/rq** & $\Lambda / \uparrow \wedge * *$ & $11 / \wedge * *$ & r/frR* & rTDI/*** & $\wedge$ & $r$. \\
\hline$\Lambda|\xi| * *$ & $r / \Delta V^{* *}$ & $\cdot / \cdot \wedge \vee^{* *}$ & f/99** & $1 / \Delta \& * *$ & $\varepsilon / 9 \Delta * *$ & $\Lambda / \wedge \Lambda * *$ & $1 / 91 * *$ & 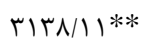 & $\wedge$ & f. \\
\hline $1 / \uparrow \& * *$ & F/A $V^{* *}$ & $\cdot|\cdot v| * *$ & $V / F \uparrow * *$ & $1 / 9 \mu * *$ & s/rq** & $9 / \Delta \Delta * *$ & $|/ 4| * *$ & TETV/AF** & $\Lambda$ & $\Delta \cdot$ \\
\hline
\end{tabular}


عجريبزاده و همكاران: اثر دكر آسيبى غلظتهاى متفاوت عصاره آبى نه تونه علف هرز بر شاخصهاى جوانهزنى...

جدول f - مقايسه ميانگين اثر دكرآسيبى عصاره آبى 9 گَونه علف هرز در غلظت •ا آرم در ليتر بر شاخصهاى جوانهزنى و رشد انيسون

\begin{tabular}{|c|c|c|c|c|c|c|c|c|c|}
\hline شاخص & شنيه كَاخص طولى & 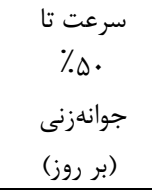 & ساقه & وزيش خشه & ساقه & (ميلمىمتر) & جوانهزنى & جوانهزنى درصد & علفع عصاره \\
\hline$\Lambda / \Delta \& b c$ & $1 \cdot 19 \cdot \mathrm{cd}$ & $\cdot 11 \cdot r \mathrm{c}$ & $q / v \Delta b$ & $r / a \cdot b$ & $N / r \cdot b c$ & A/rrbcd & $r / \wedge b c$ & $9 \wedge c^{*}$ & ازمك \\
\hline $9 / \Delta 9 \mathrm{c}$ & N/Vrcd &.$/ 11 \mathrm{fa}$ & $\mathrm{V} / \mathrm{V} \Delta \mathrm{b}$ & $r / V \Delta b$ & 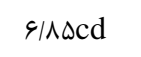 & $\mathrm{V} / \mathrm{TCd}$ & $1 / \wedge \mathrm{rcd}$ & gred & آلاله وحشى \\
\hline $\mid r / \Delta \& b$ & $\mid r / r \Delta b c d$ &.$/ 11 \mathrm{fa}$ & $1 \cdot / r \Delta b$ & $9 / 0 \cdot a$ & $V / q \cdot b c$ & $\Lambda / 4 \mathrm{Vbcd}$ & $r / \varphi q a$ & $v \Delta a b$ & وحشى \\
\hline$N / D F b c$ & $\mid r / \wedge \vee b c$ & $\cdot / 1 \cdot \Delta b c$ & $1 \cdot 1 \cdot \cdot b$ & $r / v \Delta b$ & $\mathrm{~V} / \cdot \Delta \mathrm{bcd}$ & $\mid q / \cdot \Delta b$ & $1 / \wedge \mathrm{rcd}$ & s Vcd & كاهو وحشى \\
\hline V/rrc & Ir/VYbcd & $\cdot / \cdot r c$ & $q / \cdot \cdots b$ & $r / \cdot b b$ & $\Lambda / r \Delta a b c$ & $1 \% / 9 \vee \mathrm{bc}$ & $1 / 9 \mathrm{Vd}$ & $9 \cdot \mathrm{e}$ & جغجغك \\
\hline$V / 1 \cdot c$ & 9/9rd & $\cdot / 1 \cdot \mathrm{Vabc}$ & $v / \cdot \cdot b$ & $r / \cdot b b$ & $\Delta / 1 \cdot d$ & $F / \& V d$ & $r / \cdot 9 b c$ & vibc & بىتيراخ \\
\hline$\wedge / \uparrow \wedge b c$ & $\mid \wedge / 1 \Delta b$ & $\cdot / 11 \cdot a b c$ & $\Lambda / \vee \Delta b$ & $r / \cdots b$ & q/Vrab & $\mid r / r \cdot b$ & r/rqab & v१a & بارهنت \\
\hline IV/Gra & $I r / r V c d$ &.$/ 11 \mathrm{rab}$ & $19 / r \Delta \mathrm{a}$ & $r / \cdot b b$ & g/9rcd & $\wedge / \wedge \Delta b c d$ & $r / \Delta \omega \mathrm{a}$ & vqa & علف يشمكى \\
\hline IV/rra & re/fra & $\cdot / 1 \cdot r c$ & $1 \Delta / v \Delta a$ & $4 / \cdot \cdot \mathrm{a}$ & $11 / \cdot \cdot a$ & rT/rDa & r/r^ab & $\mathrm{V} 9 \mathrm{a}$ & خاشك كل \\
\hline \multicolumn{10}{|c|}{ 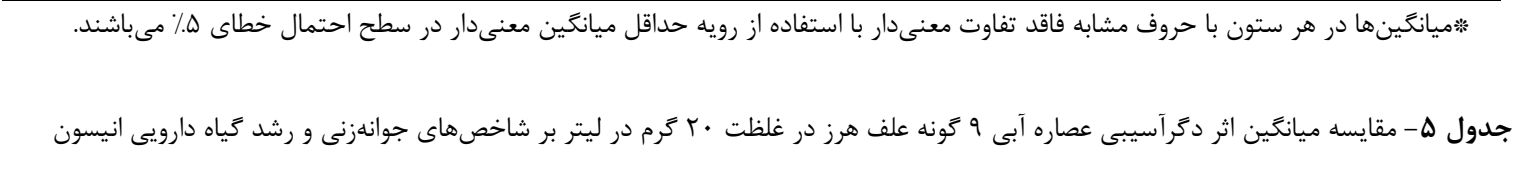 } \\
\hline شياهن بنه & شاخص & 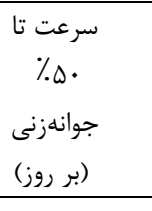 & ساقه خه خهـ & روزن خشه & ساقه ֶه & (ميلى ريهتر ) & جوانهزنى & جوانهزنى درصد & علفع عصاره \\
\hline$\cdot e$ & $\cdot \mathrm{e}$ & $\cdot d$ & $\cdot \mathrm{c}$ & $\cdot d$ & $\cdot d$ & $\cdot d$ & $\cdot \mathrm{e}$ & $\cdot \mathrm{f}^{*}$ & ازمك \\
\hline$\cdot \mathrm{e}$ & $\cdot e$ & $\cdot d$ & $\cdot c$ & $\cdot d$ & $\cdot d$ & $\cdot d$ & $\cdot \mathrm{e}$ & $\cdot f$ & آلاله وحشى \\
\hline$|r /| \cdot b c$ & G/VVcd & $\cdot / 1 \cdot r b c$ & $11 / a \cdot b$ & $\Delta / \cdot \cdots \mathrm{a}$ & $f / f \Delta b c$ & $\mathrm{~F} / \mathrm{V} \cdot \mathrm{c}$ & $\tau / \cdot \wedge b$ & $V \notin b$ & وحشى يولاف \\
\hline$\cdot e$ & $1 / 1 \cdot e$ & $\cdot / 1 \cdot r b c$ & $\cdot \mathrm{c}$ & $\cdot d$ & $\cdot d$ & $r / \cdots d$ & $1 / \Delta r d$ & $\Delta \Delta \mathrm{e}$ & كاهو وحشى \\
\hline $9 / r r c d$ & $|f /| \vee a b$ & $\cdot / 11 \mathrm{Va}$ & $11 / v \Delta b$ & $r / \cdot b b$ & 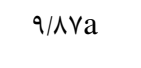 & $\mid r / 9 V a$ & $1 / 9 \Delta \mathrm{bc}$ & srd & جغجغك \\
\hline$r / \cdot 1 \mathrm{e}$ & $4 / \cdots \mathrm{d}$ & $.1 .94 \mathrm{c}$ & $r / \cdots c$ & $1 / \cdot c \mathrm{~cd}$ & $f / T \Delta c$ & $F / V \cdot c$ & I/Nrcd & svcd & بى تيراخ \\
\hline $\mid r / F r b$ & $I r / V V b$ & $\cdot / 1 \cdot 9 \mathrm{~b}$ & $|\mathrm{~V}| \cdot \cdot \mathrm{a}$ & $r / r \Delta \mathrm{bc}$ & G/VYb & $11 / 9 \Delta \mathrm{a}$ & $1 / 9 \Delta b c$ & $99 b c$ & بارهنت \\
\hline $19 / .9 a$ & $|\varepsilon| \cdot r a$ & $\cdot / 111 \mathrm{ab}$ & $19 / \cdots a$ & $r / v \Delta a$ & $9 / r \vee a$ & $1 \cdot / v \Delta \mathrm{a}$ & $r / \& \varepsilon a$ & $\wedge \cdot a$ & علف يشمكى \\
\hline G/D 9d & $\Lambda / 9 \Delta c$ & $\cdot / 1 \cdot r b c$ & $\Lambda / r \Delta b$ & $1 / \cdot c \mathrm{~cd}$ & $\Delta / \Delta r b c$ & $V / q \cdot b$ & $1 / 91 \mathrm{bc}$ & $99 \mathrm{bc}$ & ماشك گل \\
\hline
\end{tabular}




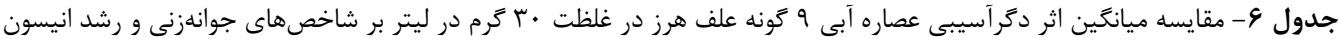

\begin{tabular}{|c|c|c|c|c|c|c|c|c|c|}
\hline شياخص & طاخص & 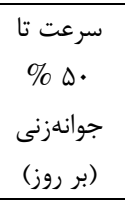 & وزاقه خشه & وزيش خشه & ساقه & ريشه & جوانهزنى & جوانهزنى درصد & علف عهرز \\
\hline$\cdot c$ & $\cdot d$ & $\cdot e$ & $\cdot c$ & $\cdot \mathrm{c}$ & $\cdot e$ & . & $\cdot g$ & $\cdot \mathrm{f}^{*}$ & ازمك \\
\hline$\cdot c$ & $\cdot d$ & $\cdot e$ & $\cdot c$ & $\cdot \mathrm{c}$ & $\cdot \mathrm{e}$ & $\cdot \mathrm{c}$ & $\cdot g$ & $\cdot \mathrm{f}$ & آلاله وحشى \\
\hline$\cdot c$ & $r / \Lambda \cdot c d$ & $\cdot / \cdot \wedge r b c$ & $\cdot c$ & $\cdot c$ & $r / \cdots d$ & $r / \cdots c$ & $1 / 99 \mathrm{bc}$ & $v \cdot a b$ & يولاف وحشى \\
\hline$\cdot c$ & $\cdot N \cdot d$ & $\cdot / \cdot \vee q b c$ & $\cdot c$ & $\cdot c$ & $\cdot e$ & $r / \cdots c$ & - NGe & roe & كاهو وحشى \\
\hline$\cdot c$ & $.19 \mathrm{rd}$ & $.1 .9 \mathrm{Vd}$ & $\cdot c$ & $\cdot c$ & $\cdot \mathrm{e}$ & $r / \cdots c$ & $\cdot / \Delta \Delta f$ & rre & جغجغك \\
\hline$\cdot c$ &.$/ 9 v d$ & $\cdot / \cdot v \wedge c$ & $\cdot c$ & $\cdot c$ & $\cdot \mathrm{e}$ & $r / \cdots c$ & $1 / \cdots d$ & $\forall \wedge d$ & بىتيراخ \\
\hline$N / r \mid b$ & $1 N / g r b$ & $\cdot / 1 \cdot \mathrm{ra}$ & $11 / r \Delta b$ & $1 / a \cdot b$ & $\Lambda / v \cdot b$ & $r \cdot / \Delta r a$ & $1 / v 9 b$ & sqbc & بارهنَ \\
\hline $19 / \pi \mathrm{ra}$ & $r \Delta / \Lambda \vee a$ & $\cdot / 1 \cdot \Delta \mathrm{a}$ & $|\varepsilon| \cdot \cdot \mathrm{a}$ & $\Delta / \Delta \cdot a$ & $\mid r / r \cdot a$ & $r \cdot / 9 \Delta \mathrm{a}$ & $\mathrm{r} / \mathrm{fra}$ & $v \Delta \mathrm{a}$ & علف پشمكى \\
\hline$q / 4 \& b$ & $9 / 1 \cdot c$ & $\cdot / \cdot \wedge \vee b$ & $q / \cdots b$ & $41 \cdot \cdot \mathrm{a}$ & $\mathrm{f} / \mu \cdot \mathrm{c}$ & $\Delta / f \cdot b$ & $1 / 49 c$ & $q \mu \mathrm{c}$ & ماشك گل \\
\hline
\end{tabular}

\begin{tabular}{|c|c|c|c|c|c|c|c|c|c|}
\hline شَاخص & طاخص كياهجه بنيه & 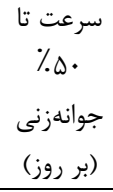 & وزن خاقه خه & وزيش خشك & ساقه & (ميلى & جوانهزنى سرعت & جوانهزنى درص & علف عصرز \\
\hline$\cdot c$ & $\cdot d$ & $\cdot \mathrm{e}$ & $\cdot \mathrm{c}$ & $\cdot c$ & $\cdot \mathrm{e}$ & $\cdot b$ & $\cdot \mathrm{e}$ & $\cdot c$ & ازمك \\
\hline$\cdot c$ & $\cdot d$ & $\cdot e$ & $\cdot c$ & $\cdot c$ & $\cdot \mathrm{e}$ & $\cdot b$ & $\cdot \mathrm{e}$ & $\cdot c$ & آلاله وحشى \\
\hline$\cdot c$ & $r / T \cdot c d$ & $\cdot / \cdot \wedge \vee \mathrm{Vbc}$ & $\cdot c$ & $\cdot c$ & $r / \cdots d$ & $r / \cdots b$ & $1 / r \Delta a$ & $\Delta \Delta \mathrm{a}$ & بولاف وحشى \\
\hline$\cdot c$ & $\cdot d$ & $\cdot e$ & $\cdot c$ & $\cdot c$ & $\cdot \mathrm{e}$ & $\cdot b$ & $\cdot \mathrm{e}$ & $\cdot c$ & كاهو وحشى \\
\hline$\cdot c$ & $\cdot d$ & $\cdot e$ & $\cdot \mathrm{c}$ & $\cdot c$ & $\cdot e$ & $\cdot b$ & $\cdot \mathrm{e}$ & $\cdot c$ & جنجغك \\
\hline$\cdot c$ & $\cdot 19 \mathrm{Vd}$ & $\cdot / \cdot \wedge \& \mathrm{c}$ & $\cdot c$ & $\cdot c$ & $\cdot e$ & $r / \cdots b$ & $\cdot / \mathrm{VVc}$ & $r+b$ & بىتيراخ \\
\hline $\mathrm{r} / \mathrm{q} \mathrm{cb}$ & $q / 4 \vee b$ & $\cdot / \cdot \mathrm{v} \Delta \mathrm{d}$ & $f / \cdots b$ & $1 / \cdot b$ & $\mathrm{~V} / \cdots \mathrm{b}$ & $11 / \cdot \Delta \mathrm{a}$ & $1 / \cdot \Delta b$ & Dra & بارهنَ \\
\hline$\Delta / 1 r a$ & $\mid Q / \mathcal{E V a}$ & $.1 \cdot 9 \Delta \mathrm{a}$ & $\mathrm{V} / \cdot \cdot \mathrm{a}$ & $1 / v \Delta a$ & $1 \cdot \pi r a$ & $19 / 1 \Delta a$ & $1 / \Delta \Delta a$ & $\Delta 9 \mathrm{a}$ & علف يشمكى \\
\hline r/Arab & $F / D \cdot c$ &.$/ .9 \mathrm{rab}$ & $f / r \Delta a b$ & $r / \cdots a$ & $r / \boldsymbol{r} \cdot \mathrm{c}$ & $f / l \Delta b$ & $1 / 4 \Delta a$ & $\Delta \vee a$ & ماشك گل \\
\hline
\end{tabular}


عجريبزاده و همكاران: اثر دتر آسيبى غلظتهاى متفاوت عصاره آبى نه كونه علف هرز بر شاخصهاى جوانهزنى...

جدول ^- مقايسه ميانكين اثر دحرآسيبى عصاره آبى 9 گَونه علف هرز در غلظت •ه گَرم در ليتر بر شاخصهاى جوانهزنى و رشد انيسون

\begin{tabular}{|c|c|c|c|c|c|c|c|c|c|}
\hline وزنى بناخص & 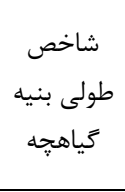 & 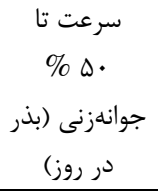 & وزاقه خشه & وزن ريشه خشه & ساقه & ريشه & جوانهزنى سرعت & جوانهزنى & نوع عصاره \\
\hline$\cdot \mathrm{c}$ & $\cdot c$ & $\cdot e$ & $\cdot d$ & $\cdot c$ & $\cdot \mathrm{c}$ & $\cdot c$ & $\cdot \mathrm{f}$ & $\cdot \mathrm{e}$ & ازمك \\
\hline$\cdot c$ & $\cdot c$ & $\cdot e$ & $\cdot d$ & $\cdot c$ & $\cdot \mathrm{c}$ & $\cdot c$ & $\cdot \mathrm{f}$ & $\cdot e$ & آلاله وحشى \\
\hline$\cdot c$ & $\cdot 19 \cdot c$ & $\cdot / \cdot \wedge \mathrm{rb}$ & $\cdot d$ & $\cdot c$ & $\cdot c$ & $r / \cdots c$ & $.19 \mathrm{Vd}$ & $r \cdot c$ & بولاف وحشى \\
\hline$\cdot c$ & $\cdot c$ & $\cdot e$ & $\cdot d$ & $\cdot \mathrm{c}$ & $\cdot \mathrm{c}$ & $\cdot \mathrm{c}$ & $\cdot \mathrm{f}$ & $\cdot \mathrm{e}$ & كاهو وحشى \\
\hline$\cdot c$ & $\cdot c$ & $\cdot \mathrm{e}$ & $\cdot d$ & $\cdot \mathrm{c}$ & $\cdot c$ & $\cdot c$ & $\cdot f$ & $\cdot \mathrm{e}$ & جنجغك \\
\hline$\cdot c$ & $\cdot / r \Delta c$ & $\cdot 1 \cdot v \cdot d$ & $\cdot d$ & $\cdot \mathrm{c}$ & $\cdot c$ & $r / \cdots c$ &.$/ r q \mathrm{e}$ & $1 \mathrm{fd}$ & بى تيراخ \\
\hline$\Delta / 9 \cdot a$ & $11 / \mu \cdot a$ & $\cdot / \cdot \vee \wedge b c$ & $1 \cdot 1$. & $1 / \cdot b$ & $V / F \Delta a$ & If/vDa & $1 / 1 \cdot b$ & a $1 \mathrm{~b}$ & بارهنغ \\
\hline$\Delta / \& \wedge \mathrm{a}$ & $1 \cdot / r \Delta \mathrm{a}$ & $.1 .91 \mathrm{a}$ & $\mathrm{N} / \cdot \mathrm{b}$ & $1 / \cdot b$ & s/VVab & $9 / 9 \Delta \mathrm{b}$ & $1 / \Delta \wedge \mathrm{a}$ & sra & علف پشمكى \\
\hline$r / 4 \cdot b$ & GIVT & $\cdot / \cdot \operatorname{vacd}$ & $F / T \Delta c$ & $r / \cdots a$ & $\Delta / \Gamma \cdot b$ & $q / r r b$ & $19 \Delta c$ & $\uparrow \wedge b$ & ماشك گَل \\
\hline
\end{tabular}

برگ، ساقه، ريشه و مخلوط بود. در واقع اثرگذارى مواد دكرآسيبى بر صفت درصد و سرعت جوانهزنى مى ستواند

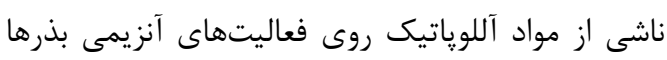
كه انتقال تركيبات ذخيرهاى در طى جوانهزنى نقش دارند، نسبت داده شود. اين امر مىتواند منجر به كمبود فرآوردهایى سوبستراهاى تنفسى و در نهايت منجر بـ به

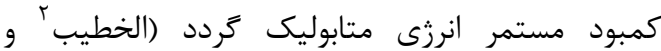

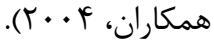

\section{طول ريشه جهه و ساقه جֶه}

بر اساس جدول مقايسه ميانگين دادهها (جدول fأ،

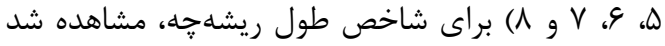

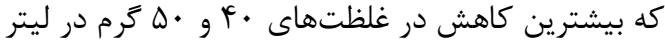
صورت گرفته است. در غلظت • ا گرم در ليتر، از تيمار عصاره آبى علفهاى هرز بيشترين كاهش طول ريشهجه انيسون نسبت به شاهد و ساير عصارهها در بىتيراخ با

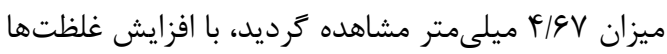

${ }^{2}$ El-Khatib
باه صفر رسيد. در واقع در ميان آللوكميكالها تركيبات حلقوى همجون فنلها، كومارينها، فلاونوئيدها، تاننها، مشتقات سيناميكاسيد و كوئينونها بلعنوان مهرمترين مواد آللوياتيكى مطرح شدهاند. فلاونوئيدها، فنلها، تاننها و و كليكوزيدها را بلعنوان تركيبهاى بازدارنده جوانهزنى

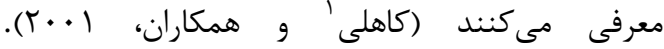
فلاونوئيدها اولين زروه از آللوكميكالهاى بازدارنده جذب اكسيرن ميتوكندريايى معرفى شدهاند كه ATP إنهيدهن در ميتوكندرى توليد مى كنند، كه اين امر منجر به ميه اثرگذارى بر تنفس شده و در نهايت كاهش جوانهزنى را

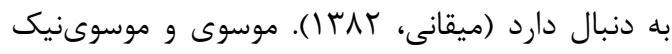

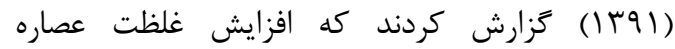
اندامهاى ازمك، باعث كاهش معنى دار درصد جوانهزنى و سبز شدن تريتيكاله شد، بهطورى كه بيشترين درصد

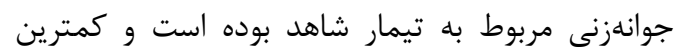
ميزان جوانهزنى مربوط به غلظت • ^ درصد اندامهاى 
رشد و توسعه آن تحت تأثير قرار مىدهد (اصغرىيور،

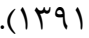

\section{وزن خشك ريشه جه و ساقه}

با توجه به جدول مقايسه ميانگين دادهها (جدول أ،

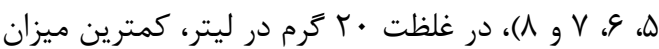
وزن خشك ريشهجه انيسون در تيمار با عصاره آبى علفهاى هرز ازمك، آلاله وحشى و كاهو وحشى مشاهده

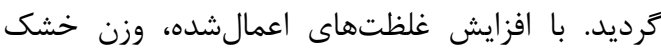
ريشهجه بهشدت تحت تأثير قراركرفته بهطورى كه در

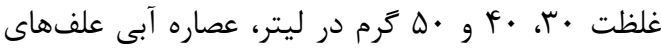

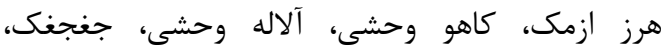
يولافوحشى و بى تيراخ بهشدت وزن خشك ريشه انيسون را كاهش داد. براى شاخص وزن خشك ساقه جهـ با توجه به جدول مقايسه ميانخين قابل ذكر است كه در در

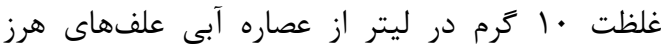
اعمالشده كمترين وزن خشك ساقهجه انيسون مربوط به تيمار عصاره آبى علف هرز بىتيراخ بود. در غلظت ونست كرم در ليتر از عصاره آبى علفهاى هرز اعمالشده كمترين ميزان وزن خشك ساقه جه انيسون مربوط به به تيمار عصاره آبى علفهاى هرز ازمك، آلاله وحشى و ورن كاهو وحشى بود. با افزايش غلظت عصاره آبى علفهاى

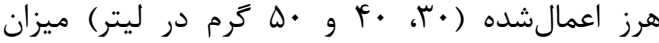

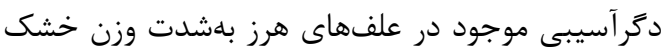
ساقهجه بذور انيسون را در تيمار عصاره آبى علفهاى مورى هرز ازمك، آلاله وحشى، كاهو وحشى، بى بيراخ، يولافوحشى و جغجغى كاهش داد.

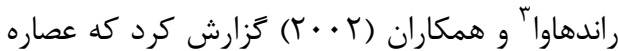
آبى حاصل از گياه سورگوم باعث كاهش وزن خشك ريشهجه Trianthema portulacastrum شده است. كاهش وزن خشك ريشهجه و واقه اثرگذارى مواد آللوشيميايى از طريق كاهش رشد ريشهجه و در نتيجه كاهش در جذب مواد غذايى و آب باشد همجنين اين مواد سبب اختلال و و كاهش در در

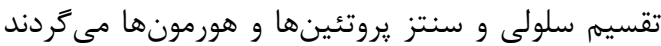

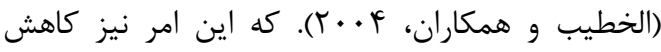

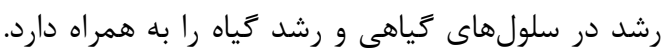

${ }^{3}$ Randhawa
اثر دكرآسيبى نيز تغيير كرده بdطورى كه در غلظت كرم در ليتر، در تيمار عصاره آبى علف هرز ازمك و آلاله وحشى طول ريشه جه بهشدت كاهش يافت. در غلظت

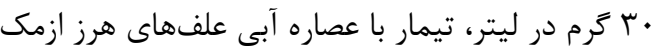
و آلاله وحشى كمترين طول ريشهجه انيسون را باعث

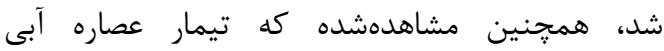

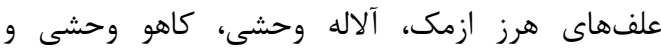

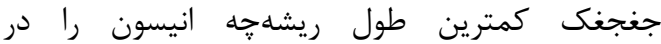
غلظتهاى • أ و • له گرم در ليتر موجب گَشت.

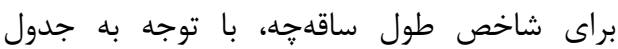

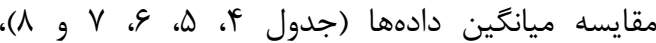
مشاهده شد كه در غلظت · •ا گرم در ليتر، كمترين طول ساقهجه انيسون در تيمار با عصاره آبى علف هرز بىتيراخ مشاهده گرديد. در غلظت • † گرم در ليتر،

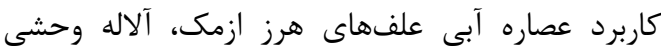
كمترين طول ساقه

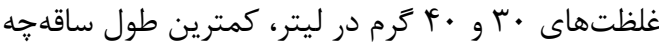
انيسون در تيمار با عصاره آبى علفهاى هرز ازمك، آلاله وحشى، كاهو وحشى، جغجغك و بىتيراخ مشاهده شد.

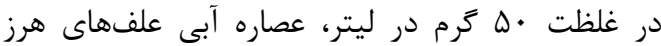

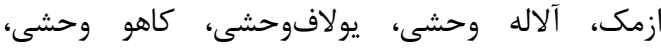

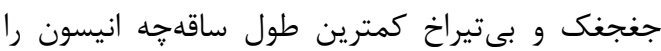

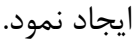
در واقع تركيبات آللوياتيكى از طريق تداخل در

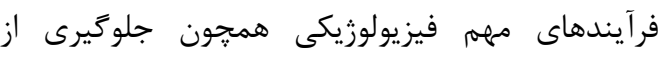
تقسيم سلولى و فعاليت برخى از آنزيمها همجيجون آلفآميلاز، برهم زدن تعادل هورمونهاى گياهى، اختلال در جذب عناصر غذايى، اختلال در تنفس و تغيير ساختار DNA و DNA مىتوانند منجر به تأخير در

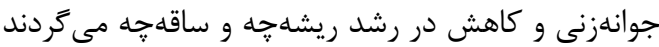

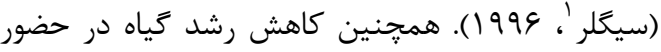

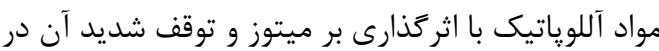

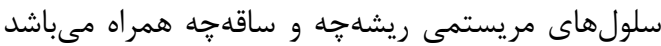

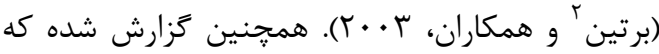
وقتى يك گياه حساس در معرض مواد آللوكميكال موجود در عصاره آبى علف هرز قرار مى گيرد، جوانهزنى،

\footnotetext{
${ }^{1}$ Siegler

${ }^{2}$ Bertin
} 
كه در غلظت • ا كرم در ليتر، كمترين شاخص وزنى بنيه كياهجه انيسون با كاربرد عصاره آبى علف هرز آنرئ آلاله

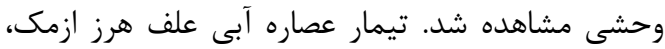

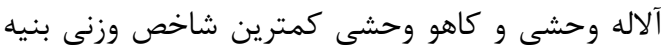

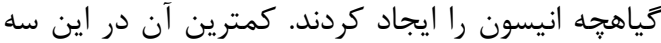

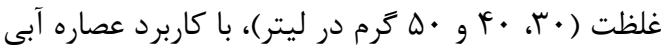

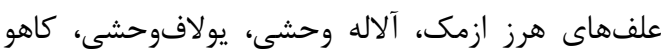
وحشى، جغجنك و بى تيراخ مشاهده شد.

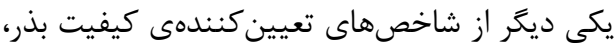

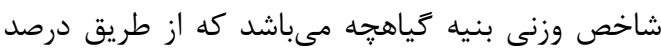

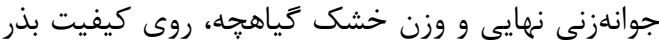
مؤثر است. بذرهايى كه داراى بنيه قوىترى باشند، توانايى بالايى در تحمل تنشهاى محيطى دارند و ضمن داشتن درصد بالايى از جوانهزنى، قادرند كياهجههاى قوىترى توليد كنند. در واقع توليد سريع، يكنواخت و والئ زياد كياهجه نشاندهنده بنيه بالاى كياه مى باشد. استقرار يك توده بذر با بنيه كم مىتواند در شرايط

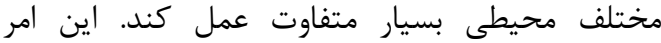
نشان دهنده اثرمتقابل بين بذر و شرايط محيطى از جمله

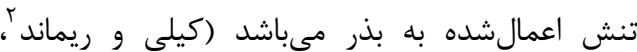

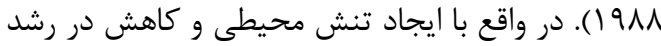

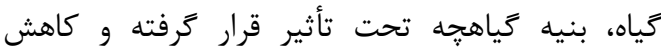
مىيابد، كه نشاندهنده اثرات مواد آللوكميكال بر اعمال

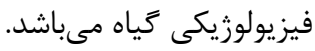

نتيجه

بطور كلى مىتوان كَفت بيشترين اثر دحرآسيبى بر جوانهزنى انيسون به ترتيب توسط عصاره آبى علف هرز

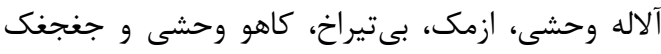
مشاهده شد و با افزايش غلظت عصاره، تمام شاخصهاى جوانهزنى روند كاهشى داشت. همجنين مشاهده شد كه

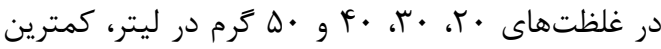
ميزان درصد جوانهزنى، سرعت جوانهزنى، سرعت تا •له درصد جوانهزنى، شاخص طولى و وزنى بنيه كياهجه، طول و وزن خشك ريشه קه و ساقهجه، از عصاره آبى آنى علف هرز ازمك و آلاله وحشى بدست آمد.

${ }^{2}$ Kelly and Raymond
موسوى و موسوىنيك (ا97|) با بررسى عصاره آبى علف هرز ازمك بر كياه تريتيكاله مشاهده كردند كه با باليا

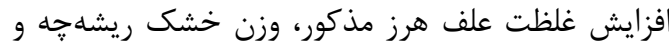
ساقه קه كاهش معنى دارى بيدا كرده است. سرعت تا •ه درصد جوانهزنى: براى شاخص سرعت تا •ه درصد جوانهزنى جداول مقايسه ميانكين

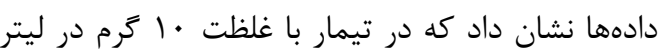

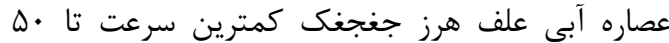

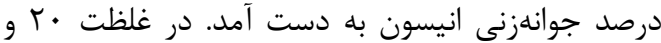
• ب كرم در ليتر تيمار عصاره آبى علفهاى هرن آند آلاله

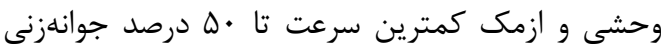

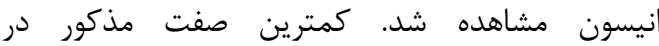
غلظتهاى • أ و •ل عرم در ليتر مربوط به تيمار عصاره آبى علفهاى هرز آلاله وحشى، ازمك، كاهو وحشى و جغجنك مىباشد. بر اساس تحقيقات انجامشده نشان داده شده است كه تركيباتى نظير ايزوتيوسياناتها كه در اثر هيدروليز كلوكوزينولاتها تحت تأثير آنزيم ميروزيناز توليد

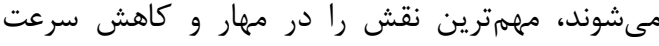

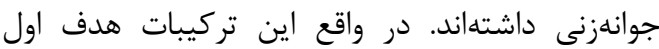
آنها، آنزيمهاى مسير كليكوليز و نيز تنفس مى باشد.

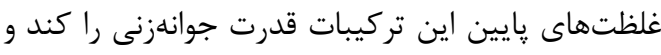

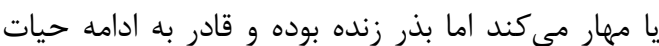

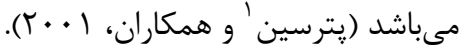

شاخص طولى و وزنى بنيه كَاهجه

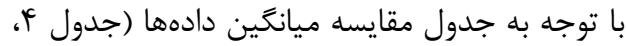
ه، و، V و A)، كمترين شاخص طولى بنيه كياهجه

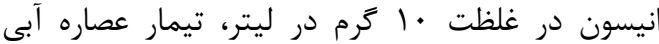

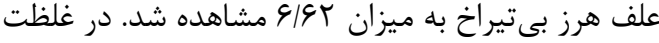

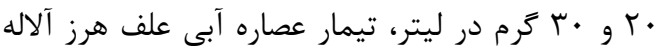
وحشى و ازمك كمترين ميزان شاخص طولى بنيه

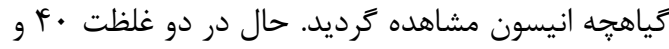

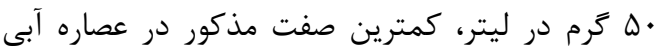

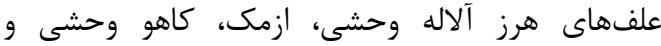
جغجغك مشاهده شد. بر اساس جداول مقايسه ميانكين

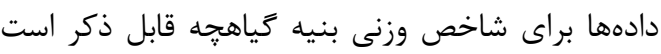

\footnotetext{
${ }^{1}$ Petersen
} 


$$
\begin{aligned}
& \text { منابع }
\end{aligned}
$$

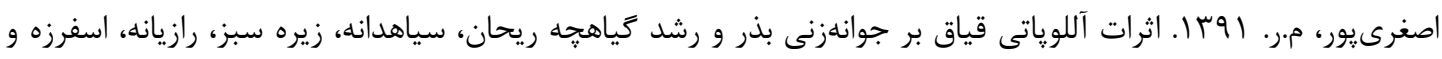

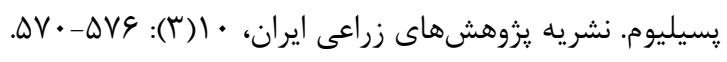

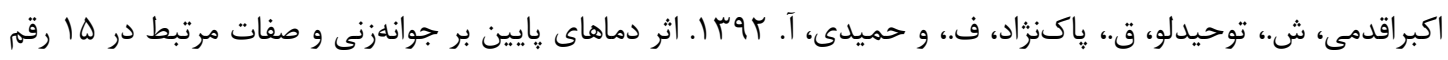

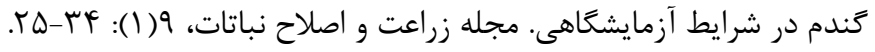

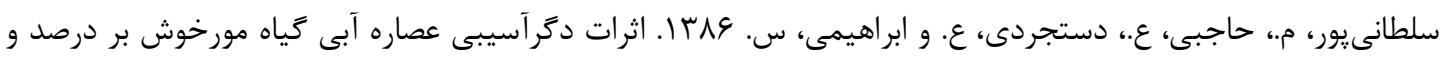

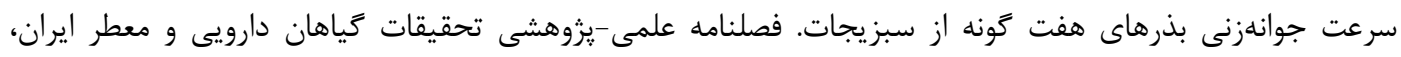

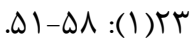

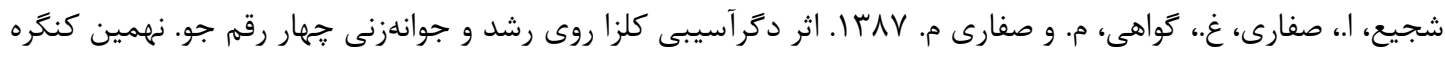

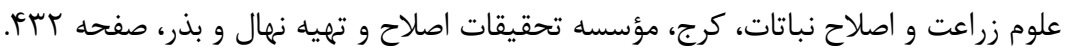

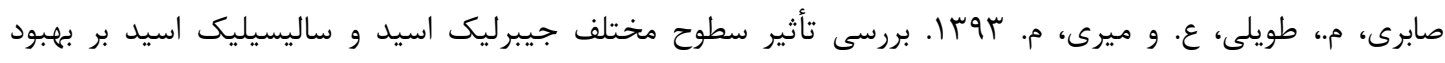

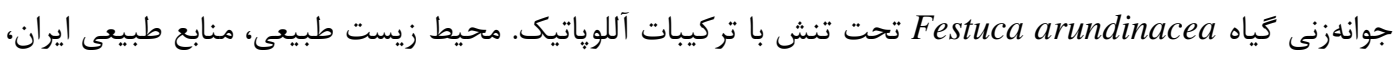

$$
\begin{aligned}
& \text { FID-FTF:(F)\&V }
\end{aligned}
$$

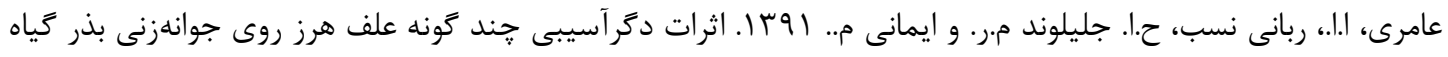

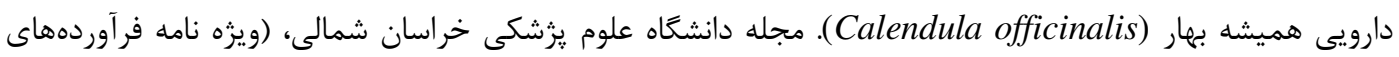

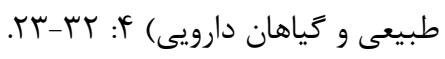

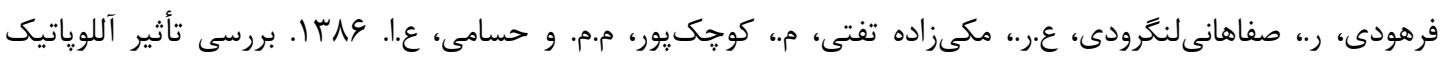

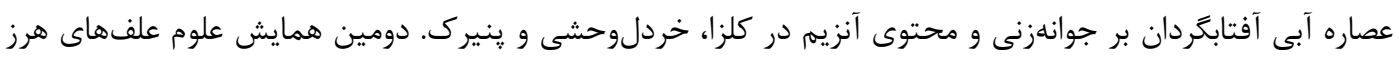

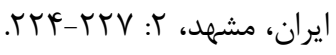

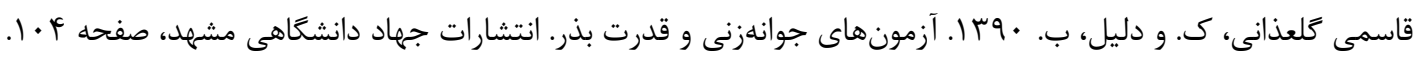

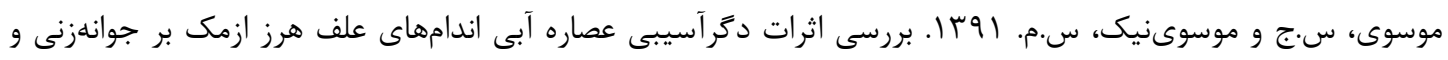

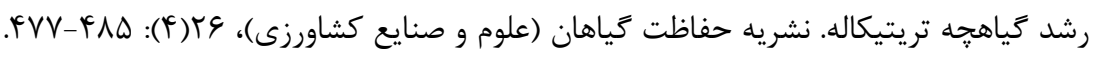

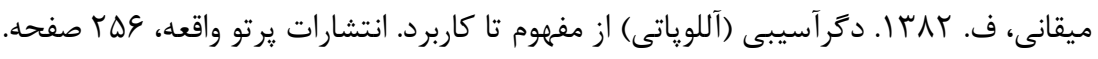

Bertin, C., Yang, X., and Weston, L.A. 2003. The role of root exudates and allelochemicals in the rhizosphere. Plant and Soil, 256(1): 67-83. https://doi.org/10.1023/A:1026290508166

El-Khatib, A.A., Hegazy, A.K., and Gala, H.K. 2004. Does allelopathy has a role in the ecology of Chenopodium murale? Annales Botanici Fennici, 41(1): 37-45.

Jabeen, N., and Molnuddin, A. 2009. Possible allelopathic effects of three different weeds on germination and growth of maize (Zea mays) cultivars. Pakistan Journal of Botany, 41(4): 16771683.

Kelly, F.A., and Raymond, A.T.G. 1988. Book Encyclopaedia of seed production of world crops. John Willy and Sons LTD, 403p.

Kohli, R.K., Singh, H.P., and Batish, D.R. 2001. Allelopathy in agroecosystems. Food Products Press, USA, 447 p.

Maguire, J.D. 1962. Speed of germination in selection and evaluation for seedling vigor. Crop Science, 2(2): 176-177. https://doi.org/10.2135/cropsci1962.0011183X000200020033x 
Narwal, S.S. 2010. Allelopathy in ecological sustainable organic agriculture. Allelopathy Journal, 25(1): 51-72.

Petersen J., Belz, R., Walker, F., and Hurle, K. 2001. Weed suppression by release of isothiocyanates from Turin rape mulch. Agronomy Journal, 93: 37-43. https://doi.org/10.2134/agronj2001.93137x

Randhawa, M.A., Cheema, Z.A., and Anjum Ali, M. 2002. Allelopathic effect of sorghum water extract on the germination and seedling growth of Trianthema portulacastrum. International Journal of Agriculture and Biology, 3: 383-384.

Regosa, M., and Pedrol, N. 2002. Allelopathy from molecules to ecosystems. Science Publishers Gnc. NH. USA, 12-195.

Seigler, S. 1996. Chemistry and mechanisms of allelopathic interactions. Agronomy Journal, 88(6): 876-885. https://doi.org/10.2134/agronj1996.00021962003600060006x

Shen, H., Guo, H., and Huang, G. 2005. Allelopathy of different plants on wheat, cucumber and radish seedlings. Journal of Applied Ecology, 16(4):740-743.

Soltani, A., Galeshi, S., Zeinali, E., and Latifi, N. 2001. Genetic variation for and interrelationships among seed vigor traits in wheat from the Caspian Sea coasts of Iran. Seed Science and Technology, 29(3): 653-662.

Soltani, A., Gholipoor, M., and Zeinali, E. 2006. Seed reserve utilization and seedling of wheat as affected by drought and salinity. Environmental and Experimental Botany, 55(1): 195-200.

https://doi.org/10.1016/j.envexpbot.2004.10.012 


\title{
Allelopathic Effect of Different Concentrations of Aqueous Extracts of Nine Weeds Species on Seed Germination and Seedling Characteristics of Anise (Pimpinella anisum)
}

\author{
Zahra Ajribzadeh ${ }^{1}$, Hamidreza Balouchi $^{2,}$,, Alireza Yadavi $^{2}$, Amin Salehi $^{3}$ \\ ${ }^{1}$ M.Sc. Student of Seed Science and Technology, Agronomy and Plant Breeding Department, \\ Yasouj University, Yasouj, Iran \\ ${ }^{2}$ Associate Professor of Agronomy and Plant Breeding Department, Yasouj University, Yasouj, \\ Iran \\ ${ }^{3}$ Assistant Professor of Agronomy and Plant Breeding Department, Yasouj University, Yasouj, \\ Iran
}

"Corresponding author, E-mail address: balouchi@yu.ac.ir

(Received: 28.08.2016 ; Accepted: 30.05.2017)

\begin{abstract}
In order to evaluate the allelopathic effect of aqueous extract of nine weeds species on Anise (Pimpinella anisum) seed germination and seedling growth characteristics, an experiment was conducted in the Laboratory of Yasouj University in 2014. This experiment was carried out as factorial with the aqueous extracts of nine weeds species, as the first factor, in different concentrations $\left(10,20,30,40\right.$ and $\left.50 \mathrm{~g} \cdot 1^{-1}\right)$, as the second factor, in a completely randomized design with four replications. The results showed that interactions between different weed aqueous extracts and concentrations had a significant impact on the germination percentage and rate, root and shoot length and weight, and vigor of anise seeds at $1 \%$ probability. The most allelopathic effects on germination percentage and rate were observed in $10 \mathrm{~g} / \mathrm{l}$ of the aqueous extract of Cowherb and Corn Buttercup, in 20 to $30 \mathrm{~g} / \mathrm{l}$ of Corn Buttercup and Whitetop, and in 40 to $50 \mathrm{~g} . \mathrm{l}^{-1}$ of Corn Buttercup, Whitetop, Wild lettuce and Cowherb, which completely stopped seed germination in Anise.
\end{abstract}

Keywords: Seedling vigor, Allelopathy, Germination percentage, Seedling growth, Bioherbicide

\section{Highlights:}

1- Allelopathic effects of 9 common weedy types on germination of Anise Seed were studied in Kohgiluyeh and Boyerahmad.

2- The effect of different concentrations of aqueous extracts of weeds on germination characteristics of anise was studied. 